more than two children who fall into the category of 'eligible' couples. Unless they get themselves sterilised within 12 months, they will not be allotted government accommodation, or, if they are already in possession of government accommodation, they will be charged standard rent; they will not be allowed any house-building advance, or loans for buying wheat or vehicles; and on being transferred, they will receive travelling allowances only for two of their children. New recruits into Haryana government service will have to undertake not to produce more than two children. A third child will render them liable to dismissal.

Days before the Haryana government decisions, the Punjab government had announced similar measures to curb the rate of population growth in that state. Among other things, women employees in Punjab would no longer be provided the facility of maternity leave and other related benefits beyond the second child.

OPEN season on the Food and Drug Administration (FDA) is, as usual, in full swing; cannon to right of them, cannon to left of them, volley and thunder, in the "health food" magazines, in Science, where the antieverything editorial staff have long used FDA as a favourite target, and even in Nature.

A new report on cyclamates says that "a blue-ribbon scientific panel" tentatively concluded on December 10 (with one dissentient) that more than 20 new studies with animals failed to show cancer, birth defects or genetic damage. Now what happens? If cyclamates are put back in soft drinks, the Center for Lawyers in the Performing Arts will erupt in rage, aided by FDA's in-house consumerist, who will inject chick embryos with cyclamates. The embryos will die. Chickens, unlike dogs, are expendable. (But what dog ever laid a nice, fresh breakfast egg?) The FDA will be accused of collaborating and conniving with the pharmaceutical industry to put a poison in our food.

However, if cyclamates are not put back in soft drinks, the Toby Belch Society, or some other watchful guardian of the obese, will protest angrily. The FDA will be accused of plotting and conspiring with the sugar industry to keep a harmless sweetener from people who need it in reducing diets. The FDA must indeed feel grateful for the existence of cyclohexylamine, a metabolic product of cyclomates that may give the regulators a little breathing spell while it is further investigated. Few of the critics will bother to read the Federal

\section{Commission foresees 200-mile limit}

THE European Commission has recently disclosed details of proposals regarding European fishing policy, grasping in the process the nettle that the problem of 200-mile fishing limits represents.

The plans, which now require a decision from the nine member governments, envisage a time when 200-mile fishing limits are approvedmost likely at a forthcoming session of the UN Law of the Sea Conference. Member governments are enjoined to formulate a common position on the issue.

The Commission emphasises the need for conservation of fish resources in its proposals, and this would probably involve setting catch quotas. The inland waters of each of the nine member states should, it says, be opened to fishermen from other member states

Food, Drug and Cosmetic Act, which gives very specific directives for evaluating applications for the use of food additives.

Some confusion in this general field undoubtedly arises from lack of understanding of the "GRAS"

\section{The policeman's lot}

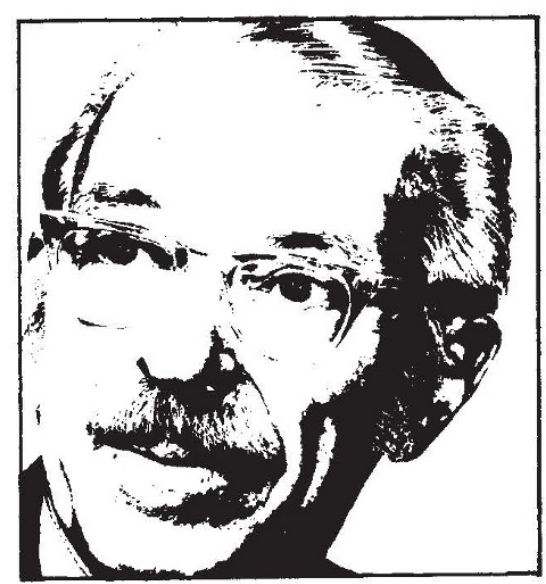

\section{THOMAS H. JUKES}

(generally recognised as safe) list. This list, which is currently being overhauled, includes about 670 substances recognised in 1958 as suitable for food, compiled from FDA food standards, from State regulations, and from lists of substances "known to have been used in food for some years without reported adverse effects." Long custom rather than scientific investigation led to the acceptance of most of these as (or in) foods. Undoubtedly, many of them would not "make it" if intro- (this is due to happen after 1982), and argues that special arangements will have to be made to protect inshore fishermen and preserve fish stocks when limits are extended to 200 miles.

Quotas would have to be negotiated with non-member countries like Spain and Norway, the Commission says, and access terms for Community fishermen in their waters would also have to be agreed.

In Norway itself, meanwhile, the minister in charge of questions relating to the law of the sea, Mr Jens Evensen, has spoken about the sort of agreements he foresees regarding conservation and quotas. He was indicating new guidelines for Norway's negotiations with 15 countries about the establishment of its proposed 200-mile economic zone. The total catch, he said, should be allotted to the various countries with a clear preference for the coastal states. And he described the EEC fisheries policies as a "heavy burden for Europe".

duced as "new" food additives. The FDA appears to be getting blamed for allowing bacon, containing mutagenic substances, to be sold. Just who got the idea of soaking meat in nitrates to preserve it is not clear, but the practice certainly antedates the FDA, and the present century. For that matter, the treatment of meat with smoke adds carcinogens to the diet, and this process must have originated in the caves of our remote ancestors.

The FDA points out that, for all food additives, new information casting doubt on safety will lead to "necessary measures provided for in the law to be undertaken to protect the public health." Actually, some additives, such as safrole, have been quietly dropped. There are no provisions, of course, for using new information of a positive nature, such as the increase in mean life span of mice, and the partial suppression of carcinogenicity of certain aromatic amines, both reported for the antioxidant butylated hydroxytoluene (BHT), whose name is enough to make it suspect, regardless of its properties.

Meanwhile, FDA is still ducking bullets on other issues, as described in Nature (November 20). Charges of "industry favouritism" by disgruntled employees make great headlines, and nothing is duller than a rebuttal. Industry, of course, says it is straitjacketed by FDA. The pushers of the quack cancer remedy "Laetrile" say they are, too, as they lie a-basking in the sun, south of the border, down Mexico way. The policeman's lot is not a happy one. 